\title{
EFFECT OF GAMMA IRRADIATION STERILIZATION ON DRUG RELEASE FROM IN SITU FORMING INJECTABLE IMPLANT SYSTEMS
}

\author{
GAMA RADYASYONLA STERİLIZASYONUN IN SITU OLUŞAN ENJEKTE \\ EDİLEBILEN İMPLANT SYSTEMLERDEN ETKİN MADDE SALIMINA ETKİSİ
}

\section{Evren ALĞIN YAPAR, Tamer BAYKARA*}

University of Ankara, Faculty of Pharmacy, Department of Pharmaceutical Technology, 06100 Tandoğan - Ankara, TURKEY.

\section{ABSTRACT}

The objective of this study was to evaluate effect of gamma irradiation sterilization on release of granisetron hydrochloride from injectable in situ implants prepared for suppressing emesis induced by radiotherapy for 21 days. Investigated formulations contain 32\% (w/w) poly(DL-lactide-co-glycolide) 50:50 (PLGA) having varied molecular weight $\left(M_{w}\right)(12,18,34 \mathrm{kDa}), 64 \%(w / w)$ benzyl benzoate and $4 \%(w / w)$ drug. Formulations were injected by $20 G$ needle independent of polymer type at this ratio, however injectability hardened by increasing $M_{w}$ of polymer. Following injection of formulations into $10 \mathrm{ml}$ phosphate buffered saline $\mathrm{pH} 7.4$, in vitro dissolution test was carried out in a shaker bath $\left(37^{\circ} \mathrm{C}, 30 \mathrm{rpm}\right)$ for 21 days and samples were analyzed by UV spectrophotometer. Drug release profiles were obtained for non-sterile and sterile form of three different formulations. Obtained profiles showed that initial drug burst decreased by increase in $M_{w}$ of polymer and high $M_{w}$ PLGA (-COOH end uncapped) provided more uniform release profile. Drug release accelerated and injectability facilitated for all formulations after sterilization by $\gamma$ irradiation. Sterilization showed a significant effect on in vitro drug release according to dissolution comparison test values of three coupled formulations which were all except the limits of $f_{1}=0-15$ and $f_{2}=50$ 100. Consequently injectable phase sensitive polymeric systems were found as sensitive to gamma irradiation sterilization.

Key words: Gamma irradiation sterilization, Granisetron HCl, Poly(DL-lactide-co-glycolide), Injectable, In situ implant.
} 


\section{ÖZET}

Bu çalışmanın amacı, ışın tedavisi ile tetiklenen kusmayı 21 gün boyunca baskılaması amacıyla hazırlanan enjekte edilebilen in situ implantlardan granisetron hidroklorür salımına, gama radyasyonla sterilizasyonun etkisinin değerlendirilmesidir. Incelenen formülasyonlar 32\% (a/a) çeşitli molekül ă̆ırlığına (Ma) sahip (12, 18, $34 \mathrm{kDa})$ poli(DL-laktid-ko-glikolid) 50:50, 64\% (a/a) benzil benzoat ve 4\% (a/a) etkin madde içermektedir. Formülasyonlar bu oranda, polimer türünden bağımsız olarak $20 G$ iğneden enjekte edilmekte, ancak enjekte edilebilirlik polimerin Ma šndaki artış ile güçleşmektedir. Formülasyonların $10 \mathrm{ml}$ pH 7.4 izotonik fosfat tamponuna enjeksiyonunu takiben in vitro çözünme hızı testi 21 gün boyunca çalkalayıcı su banyosunda yürütülmüş $\left(37^{\circ} \mathrm{C}, 30 \mathrm{rpm}\right)$ ve numuneler UV spektrofotometre ile analiz edilmiştir. Etkin madde salım profilleri üç farklı formülasyonun steril olmayan ve olan formları için elde edilmiştir. Elde edilen profiller, başlangıç etkin madde boşalmasının polimerin Ma sıındaki artış ile azaldığını ve yüksek Ma `ı PLGA `nın (-COOH ucu açık) daha düzenli salım profili să̆ladığını göstermiştir. Tüm formülasyonların $\gamma$-radyasyonla sterilizasyondan sonra enjekte edilebilirliği kolaylaşmış ve etkin madde salımı hızlanmıştır. In vitro etkin madde salımında, sterilizasyon, üç çift formülasyonun $f_{1}=0-15$ ve $f_{2}=50-100$ limitlerinin dışında elde edilen çözünme hızı karşılaştırma değerlerine göre önemli etki göstermiştir. Sonuç olarak enjekte edilebilen faz duyarl polimerik sistemler gama radyasyonla sterilizasyona duyarlı bulunmuştur.

Anahtar kelimeler: Gama radyasyonla sterilizasyon, Granisetron HCl, Poli(DL-laktid-ko-glikolid), Enjekte edilebilen, In situ implant.

\section{INTRODUCTION}

Chronic conditions require drug delivery over prolonged periods of time. Drug delivery from an oral or transdermal system by using current technology is limited to $24 \mathrm{~h}$ and 7 days respectively, however several commercially available implants are designed to release of drug for months to years (1).

A novel biodegradable injectable polymeric system namely in situ forming implants (ISFIs) has been developed and looks very promising in drug delivery which has disclosed a delivery approach to prolonged zero-order release over 2 weeks to 6 months duration (2-4). This system is liquid, injected subcutaneously or intramuscularly and deform to semi-solid or solid matrices in contact with aqueous fluids in body or release-media and release their content in a controlled manner (2). The main parts of ISFIs are; a non-reactive synthetic biodegradable polymer preferably aliphatic polyesters such as PLGA, additive and drug which are dissolved in a biocompatible and pharmaceutically acceptable solvent. This system has several advantages over existing systems: it 
is based on pharmaceutically acceptable excipients, the fabrication process is simple, does not require toxic solvent and it is likely to have greater acceptance by patients $(5,6)$. Because of their resorption in the body, it is necessary to sterilize the complete product before application. However sterilization of such polymeric systems has great importance and has some disadvantages dependent on preferred sterilization method. For PLGA implants most preferable sterilization method is gamma irradiation which characteristically highly penetrating with a low dose rate (kGy/hour) (7). Nevertheless, it is well known that gamma irradiation sterilization may cause radiolytic degradation of the polymer which induces a dose dependent chain scission leading to a molecular weight reduction (8). The effect of gamma irradiation have been reported on the release profile of polymeric systems are different in results like; release profile of drug was not altered, decrease or increase interestingly $(9,10)$.

Granisetron, azabicyclic compound, is a potent and selective 5- $\mathrm{HT}_{3}$ receptor antagonist which is considered to be a potent anti-emetic agent in the control of nausea and vomiting induced by cancer therapy (11).

The objective of this study was to evaluate effect of gamma irradiation sterilization on the release of granisetron hydrochloride in situ injectable polymeric implant systems, in suppressing emesis induced by radiotherapy for over 21 days.

\section{MATERIALS AND METHODS}

\section{Materials}

The following chemicals were obtained from commercial suppliers: Granisetron hydrochloride (Cipla Limited, India), poly(d,l-lactide-co-glycolide) (PLGA 50:50, Resomer RG $502 \mathrm{H} \mathrm{M}_{\mathrm{w}} 12 \mathrm{kDa}$, Resomer RG $502 \mathrm{M}_{\mathrm{w}} 18 \mathrm{kDa}$, Resomer RG 503H M $34 \mathrm{kDa}$ ) (Boehringer Ingelheim $\mathrm{GmbH}$, Ingelheim, Germany), Benzyl benzoate (Sigma), Disodium hydrogenphosphate (Merck), Potassium dihydrogenphosphate (Merck), Sodium chloride (Merk).

\section{Preparation of the in situ forming drug delivery systems}

In situ implants (polymer solutions) were prepared by mixing PLGA (Resomer RG502H, Resomer RG502 or Resomer RG503H) with the solvent, benzyl benzoate (BB), in glass vials until the formation of a clear solution and then GRN HCl was added and sonicated (Bandelin Sanoplus HD 2070, Germany) to achieve a homogeneous suspension. This solution was then sealed and heated to $65^{\circ} \mathrm{C}$ to remove trapped air bubbles. For in situ implants polymer, solvent and drug 
concentration was kept constant at 32\%, 64\% and 4\% (w/w) respectively. The code and content of formulations is given in Table 1.

Table 1. The code, content (given in $\mathrm{mg}$ ) and injectability of in situ implant formulations.

\begin{tabular}{|c|c|c|c|}
\hline Content/ Code & F1 or R1 & F2 or R2 & F3 or R3 \\
\hline Resomer RG 502H & 150 & - & - \\
Resomer RG 502 & - & 150 & - \\
Resomer RG 503H & - & - & 150 \\
Benzyl Benzoate & 300 & 300 & 300 \\
GRN HCl & 20 & 20 & 20 \\
\hline Injectability (20G needle) & Yes & Yes & Yes \\
\hline
\end{tabular}

\section{Sterilization process}

Liquid implant formulations were placed in glass aluminum sealed vials and irradiated with a ${ }^{60}$ Co source (Tenex Issledovatel, TAEK, Ankara, Turkey). A $25 \mathrm{kGy}$ dose was applied following the European Pharmacopoeia recommendations for an effective sterilization (12).

\section{Drug release studies}

After injectabilities of all formulations from $20 \mathrm{G}$ needle were determined (Table 1), formulations were injected in $10 \mathrm{ml}$ phosphate buffer saline $\mathrm{pH} 7.4$ containing vials and in vitro dissolution test was carried out in a shaker bath (GFL 1086, Germany) at $30 \mathrm{rpm}$ and $37^{\circ} \mathrm{C}(\mathrm{n}=3)$. Replenished, collected and filtered dissolution media at predetermined time points (1h, 4h, 24h, once a day through 2-21 days) were analyzed by UV spectrophotometer (Shimadzu 1240, Japan) at $301 \mathrm{~nm}$ (after accomplished calibration and method validation stages) and drug release profiles were obtained. Comparison between drug release profiles of formulations and their irradiated forms were evaluated by dissolution comparison test values of $\mathrm{f}_{1}$ and $\mathrm{f}_{2}(13)$.

\section{RESULTS AND DISCUSSION}

Injectability problems are associated with polymer solutions, so the ease of injection of an in situ implant formulation into the subcutaneous tissue is an important consideration. Formulations prepared with PLGA having different $\mathrm{M}_{\mathrm{w}}$ were tested to see if they were injectable through a $20 \mathrm{G}$ needle. The results are shown in Table 1 . All formulations were injectable through a $20 \mathrm{G}$ needle. 
However upon increasing $\mathrm{M}_{\mathrm{w}}$ of polymer present in formulation became more difficult to inject and upon gamma irradiation injectability of formulations became easier to inject through the $20 \mathrm{G}$ needle.

Dissolution profiles of investigated formulations and their irradiated forms are given in Fig. 1 and Fig. 2 respectively. Highly hydrophobic non-water soluble BB was used as solvent in all formulations to control the initial burst of drug. Effect of $\mathrm{M}_{\mathrm{w}}$ and esterification of PLGA 50:50 on drug release were shown in Fig. 1.

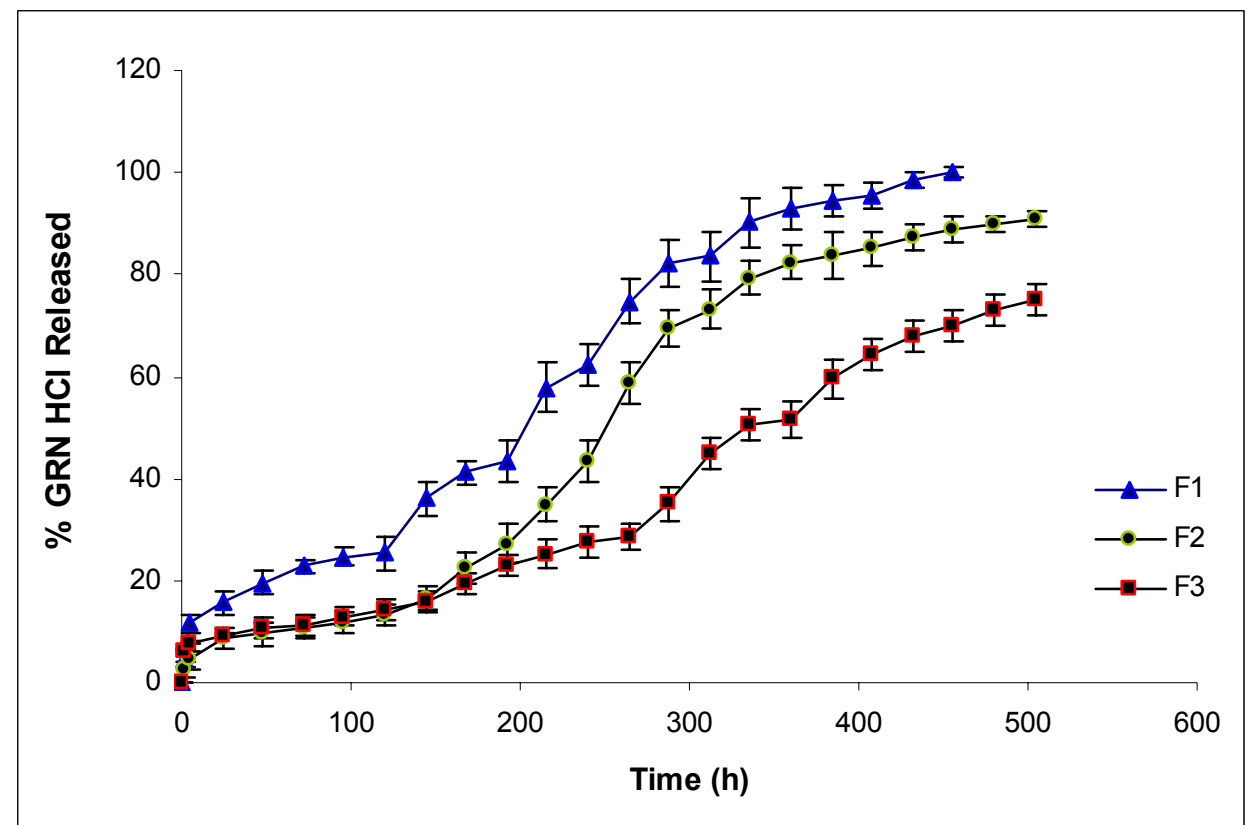

Figure 1. Dissolution profiles of F1, F2 and F3 formulations.

As seen in Fig. 1, initial and following drug release was high from F1 containing Resomer RG 502H (Mw $12 \mathrm{kDa}$ ) compared to F2 containing Resomer RG 502 (Mw $18 \mathrm{kDa}$ ) and F3 containing Resomer RG 503H (Mw $34 \mathrm{kDa}$ ). Due to low Mw and uncapped -COOH groups of Resomer RG 502H, higher release amounts of drug with an initial burst of $15.6 \%$ in the first day was obtained from this formulation (14). Uncapped - COOH groups of Resomer RG502H increased water affinity of formulation and low viscosity of formulation due to low $\mathrm{Mw}$ of polymer, facilitated entering of water inside of the formulation which was necessary for solidification. However non-water soluble BB limited the water entrance and decelerated phase separation and solidification. This complicated action resulted as an acceptable release profile for GRN $\mathrm{HCl}$. Initial drug release decreased to approximately $9 \%$ from F2 and F3 formulations due to altered polymer characteristics in these formulations compared to F1. Although having different Mw of 
PLGA, the similarity of release profiles of F2 and F3 in the first week ( $168 \mathrm{~h})$ could be attributed to esterified - $\mathrm{COOH}$ groups of Resomer RG 502

$(18 \mathrm{kDa})$ which decreased the water affinity of polymer and also formulation, conversely uncapped - $\mathrm{COOH}$ groups of Resomer RG $503 \mathrm{H}(34 \mathrm{kDa})$ which increased the water affinity of formulation probably compensated the difference in $\mathrm{Mw}$ of the polymers by means of release profiles. The increase in drug release from F2 after the first week could be explained by the low viscosity of depot which permitted to more water intake to the inside of formulation as a result of dissolved and removed drug molecules. Lower drug release obtained from F3 formulation compared to F2, could be attributed to the higher viscosity of depot which also provided relatively uniform release profile of drug. Between the 3 formulations better release profile of GRN $\mathrm{HCl}$ was obtained from $\mathrm{F} 3$ containing hydrophilic and high Mw PLGA (Resomer RG 503H) in combination with hydrophobic BB. These results are supported by some study other studies $(14,15)$.

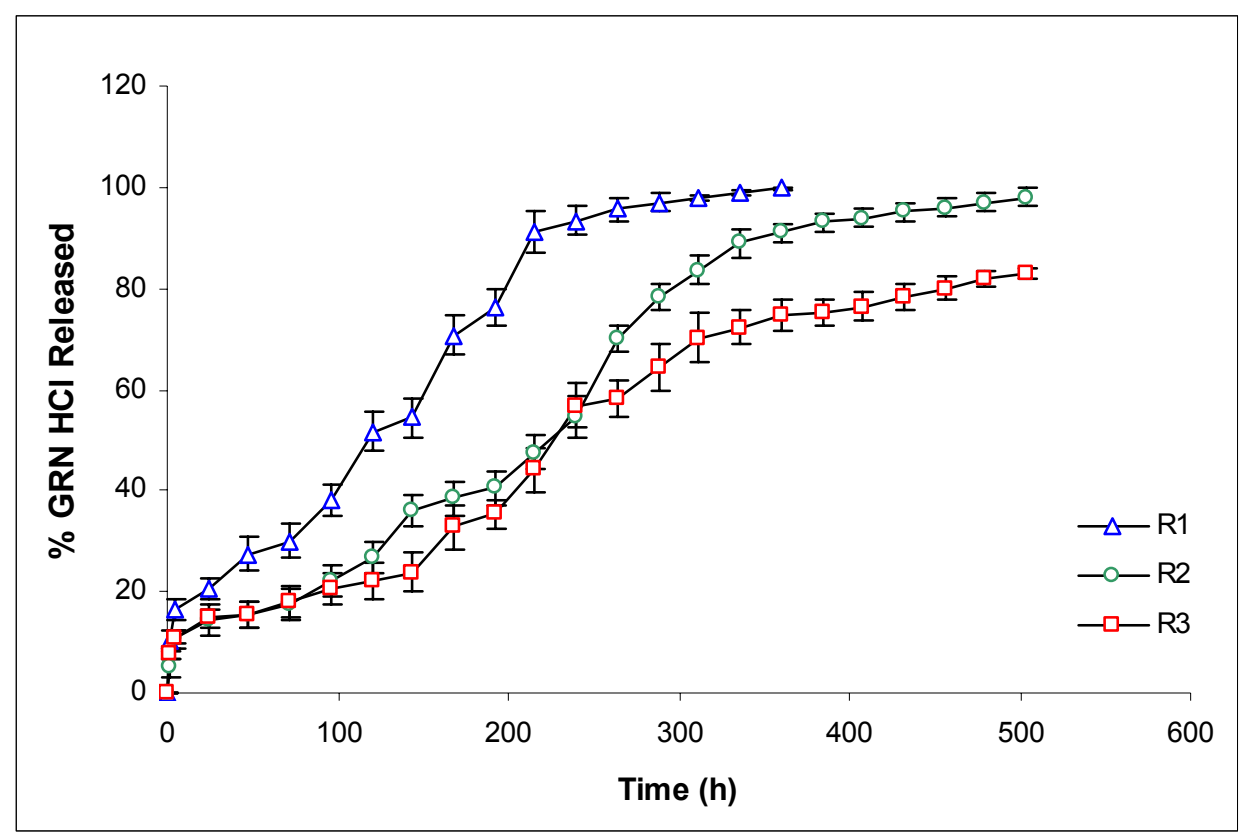

Figure 2. Dissolution profiles of R1, R2 and R3 formulations.

After application of gamma irradiation for sterilization, drug release was increased from all of formulations as seen in Fig 2. It was observed that, while release of drug increased from R1 and R3 (Fig 3 and Fig 5), it was relatively lower for R2 (Fig 4). When the comparison of the release profiles was evaluated according to dissolution comparison test values of difference factor; f1 and similarity factor; $\mathrm{f} 2$, above mentioned observation was proved with the obtained values for F1-R1, F2-R2 and F3-R3 which were far from the limits of $\mathrm{f} 1=0-15$ and $\mathrm{f} 2=50-100$ as seen in Table 2. 
However $\mathrm{fl}=24$ and $\mathrm{f} 2=41$ values obtained for $\mathrm{F} 2-\mathrm{R} 2$ was closer to the limits compared to others (Table 2). Degradation in Mw of Resomer RG 502H which has lowest Mw reflected as an increase in drug release due to low viscosity depot and hydrophilic PLGA (Fig. 3). Drug release from R2 was least affected compared to R1 and R3, probably due to esterified - $\mathrm{COOH}$ of PLGA which decreased the water affinity of formulation (Fig. 3-5). Degradation in Mw of Resomer RG 503H which has highest $\mathrm{Mw}$, reflected as an increase in drug release especially after the sixth day (144 h) (Fig. 5), probably due to higher degradation in high Mw PLGA with gamma irradiation which has accordance with the study of Ravivarapu et al. (16). Application of $25 \mathrm{kGy}$ dose of gamma irradiation to the PLGA polymer solutions prepared with BB resulted as an increase in drug release from the formulations containing different types of PLGA 50:50 polymers due to degradation in polymers (Fig. 3-5). These results are supported by the study of Bushell et al. (17).

Table 2. The $f_{1}$ and $f_{2}$ values of non-irradiated and irradiated forms of formulations.

\begin{tabular}{|c|cc|}
\hline Formulations & $\begin{array}{c}\text { Difference factor } \\
\left(\mathbf{f}_{\mathbf{1}}\right)\end{array}$ & $\begin{array}{c}\text { Similarity factor } \\
\left(\mathbf{f}_{\mathbf{2}}\right)\end{array}$ \\
\hline F1 & 30 & 29 \\
R1 & 24 & 41 \\
\hline F2 & & \\
R2 & 44 & 32 \\
\hline F3 & & \\
\hline
\end{tabular}

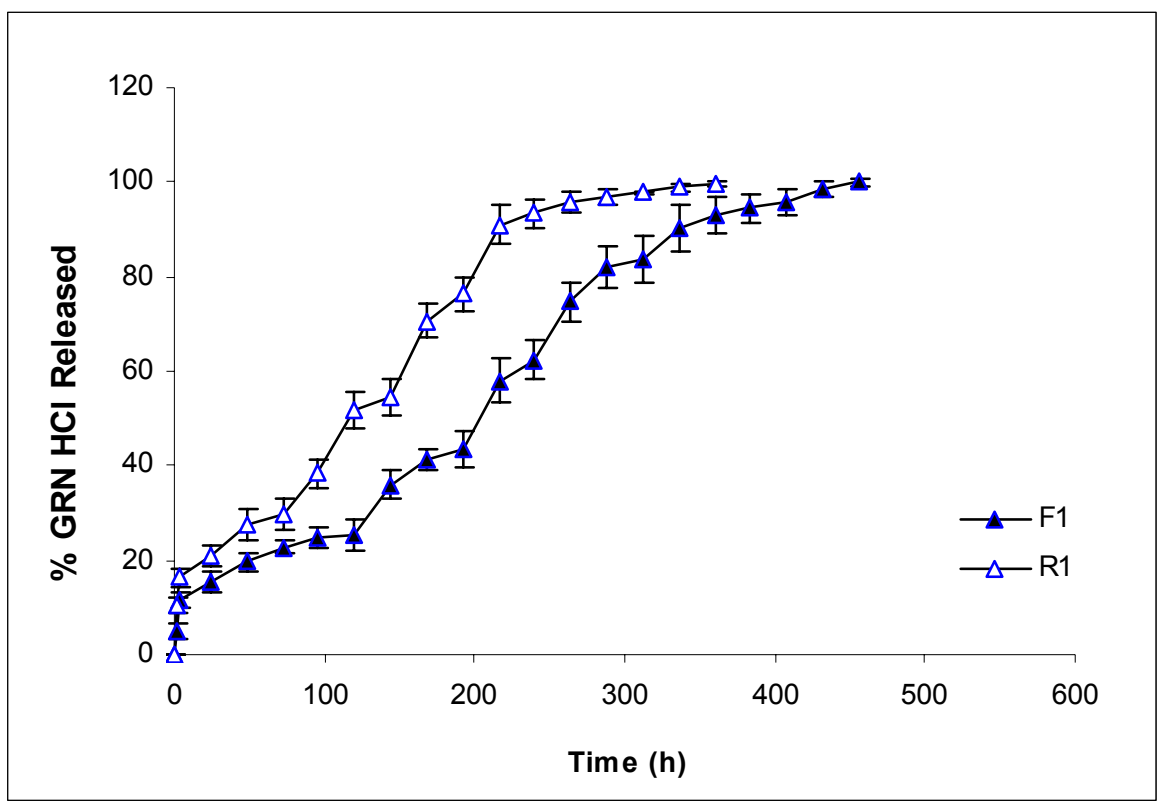

Figure 3. Dissolution profiles of F1and R1 formulations. 


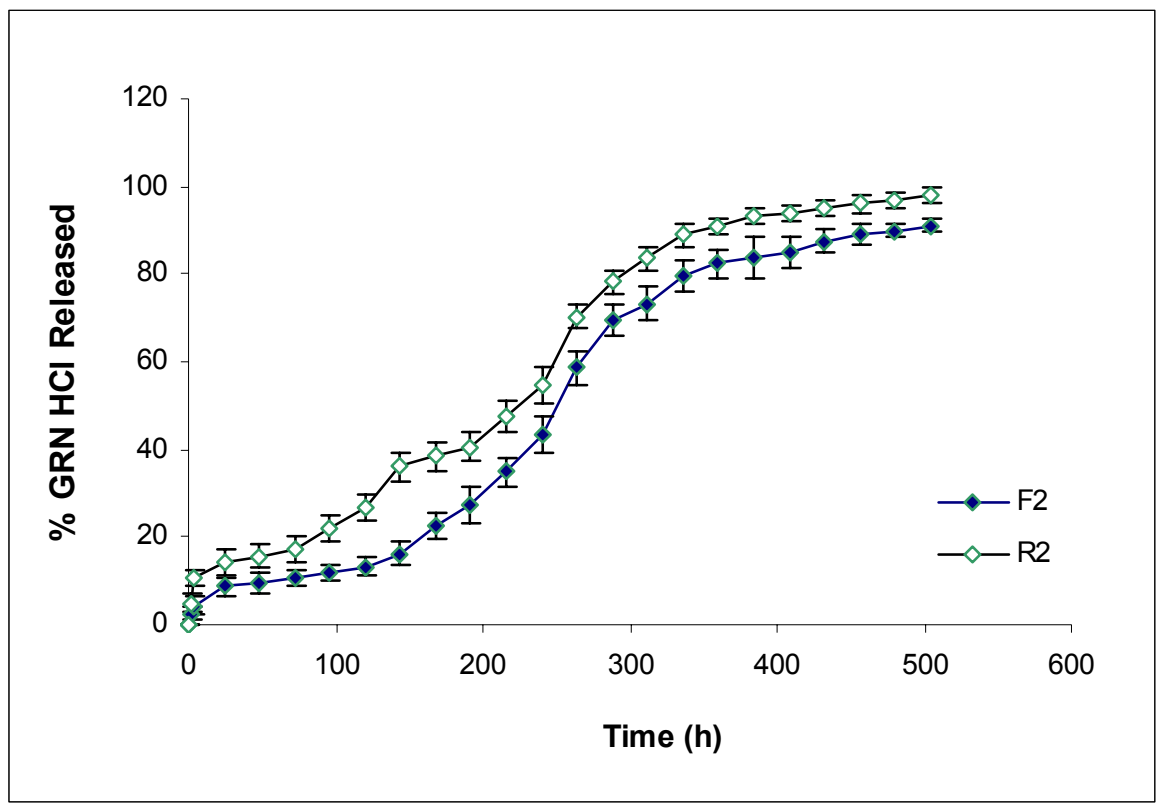

Figure 4. Dissolution profiles of F2and R2 formulations.

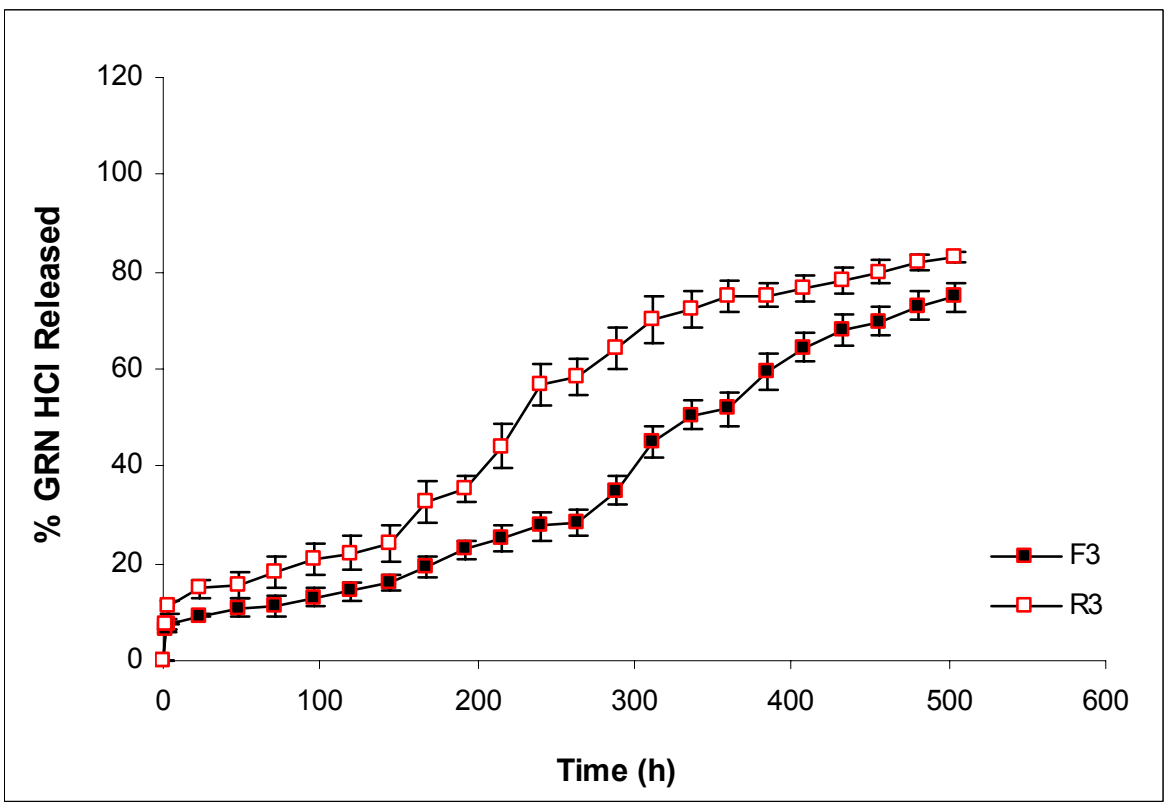

Figure 5. Dissolution profiles of F3 and R3 formulations. 


\section{CONLUSION}

As a conclusion gamma irradiation sterilization which has taken place in European Pharmacopoeia (12) was found effective on dissolution profiles of phase sensitive polymeric in situ implants. Therefore preparation of these formulations in aseptic conditions would be recommended.

\section{REFERENCES}

1- Wright, J .C., Leonard, S.T., Stevenson, C.L., Beck, J.C., Chen, G., Jao R.M. et al. "An in vivo/ in vitro comparison with a leuprolide osmotic implant for the treatment of prostate cancer" J. Control. Release, 75, 1-10, (2001).

2- Dunn, R.L., English, J.P., Cowsar, D.R., Vanderbilt, D.P. "Biodegradable in-situ forming implants and methods of producing" US Patent, 5990194, (1999).

3- Hatefi A., Amsden B. "Biodegradable injectable in-situ forming drug delivery systems" $J$. Control. Release, 80, 9-28, (2002).

4- Packhaueser, C.B., Schneiders, J., Oster, C.G., Kissel, T. "In situ forming parenteral drug delivery systems" Eur. J. Pharm Biopharm., 58, 445-455, (2004).

5- Astaneh, R., Moghimi, H.R., Erfan, M., Mobedi, H. "Formulation of an injectable implant for peptide delivery and mechanistic study of the effect of polymer molecular weight on its release behaviour" Daru, 14(2), 65-70, (2006).

6- Algın Yapar, E., Baykara, T. "Effects of solvent combinations on drug release from injectable phase sensitive liquid implants" Turkish J. Pharmaceutical Sciences, 7(1), xx, (2010), (in press).

7- Bernkopf, M. "Sterilisation of bioresorbable polymer implants" Medical Device Technology, 4, 26-29, (2007).

8- Hausberger, A.G., Kenley, R.A., Deluca, P.P. "Gamma-irradiation effects on molecular weight and in vitro degradation of poly(DL-lactide-co-glycolide) microparticles" Pharm. Res., 12(6), 851-856, (1995).

9- Igartua, M., Herna'ndez, R.M., Rosas, J.E., Patarroyo, M.E., Pedraz. J.L. " $\gamma$-Irradiation effects on biopharmaceutical properties of PLGA microspheres loaded with SPf66 synthetic vaccine" Eur. J. Pharm. Biopharm, 65(1), 91-102, (2008). 
10- Friess, W., Schlapp, M. "Sterilization of gentamicin containing collagen/PLGA microparticle composites" Eur. J. Pharm. Biopharm., 63(2), 176-187, (2006).

11- Aapro, M. "Granisetron: an update on its clinical use in the management of nausea and vomiting" The Oncologist, 9, 673, (2004).

12- European Pharmacopoeia, 6th, Council of Europe, Strasbourg Cedex, France, (2007).

13- Moore, J.W., Flanner, H.H. "Mathematical Comparison of curves with an emphasis on in vitro dissolution profiles" Pharm. Tech., 20(6), 64-74, (1996).

14- Luan, X., Bodmeier, R. "In situ forming microparticle system for controlled delivery of leuprolide acetate: influence of the formulation and processing parameters" Eur. J. of Pharm. Sci., 27, 143-149, (2006).

15- Astaneh, R., Erfan, M., Moghimi, H.R., Mobedi, H. "Changes in morphology of in situ forming plga implant prepared by different polymer molecular weight and its effect on release behavior" J. of Pharm. Sci., DOI 10.1002/jps.21415, (2008).

16- Ravivarapu, H.B., Moyer, K.L., Dunn, R.L. "Sustained activity and release of leuprolide acetate from an in situ forming polymeric implant" AAPS Pharm. Sci.Tech., 1(1), 1-8, (2000).

17- Bushell, J. A., Claybourn, M., Williams, H.E., Murphy, D.M. “An EPR and ENDOR study of g- and h-radiation sterilization in poly (lactide-co-glycolide) polymers and microspheres" $J$. Control. Release, 110, 49-57, (2005).

Received: 09.07.2009

Accepted: 30.07 .2009 